\title{
Radiation-hypersensitive cancer patients do not manifest protein expression abnormalities in components of the nonhomologous end-joining (NHEJ) pathway
}

\author{
T Leong', M Chao', S Bassal' and M McKay*,', \\ 'Peter MacCallum Cancer Institute, Smorgon Family Building, St Andrews Place, East Melbourne, Victoria 3002, Australia
}

\begin{abstract}
Radiation therapy (RT) is utilised for the treatment of around half of all oncology patients during the course of their illness. Despite great clinical progress in the rational deployment of RT, the underlying molecular basis for its efficacy and toxicity are currently imperfectly understood. In this study, we took a biochemical approach to evaluate the potential role of key ionising radiation repair proteins in the treatment outcomes of patients with severe acute or late RT side effects. Lymphoblastoid cell lines were established from blood samples from 36 radiosensitive cases and a number of controls (the latter had had RT but did not develop significant toxicity). The expression level and migration of key proteins from the nonhomologous end-joining (NHEJ) pathway was evaluated by Western blot analysis on cases and controls. We did not observe any abnormalities in expression level or migration pattern of the following NHEJ proteins in radiosensitive cancer cases: Ku70, Ku80, XRCC4, DNA Ligase IV. These important negative results provide evidence that mutations that affect protein expression of these NHEJ components are unlikely to underlie clinical radiation sensitivity.

British Journal of Cancer (2003) 88, I25 I-1255. doi:I0.I038/sj.bjc.6600897 www.bjcancer.com
\end{abstract}

(C) 2003 Cancer Research UK

Keywords: radiation sensitivity; NHEJ; DNA double strand breaks; cancer; radiotherapy

There is a range in the severity of normal tissue reactions observed when cancer patients receive standard radiotherapy (RT) treatment. Some individuals develop severe normal tissue reactions such as small bowel damage following pelvic irradiation or myelopathy following irradiation of the spinal cord. Normal tissue RT tolerance is dependent on many factors including dose, fractionation, the volume irradiated and individual variation in radiation sensitivity (McKay and Peters, 1997). The doses prescribed in current practice are largely based on the clinically determined tolerance of the normal tissues in the radiation field, and have evolved to limit the proportion of highly radiosensitive adverse reactions to about $0.5-5 \%$ of cases, depending on factors such as the end point under consideration (Norman et al, 1988). If it were possible to identify these ionising radiation (IR)-hypersensitive individuals in advance of therapy by the use of effective predictive assays, their treatment could be adjusted or changed and it might then be possible to escalate the dose in the remaining patients (i.e. the great majority of individuals). This would be expected to improve local tumour control and cure rates.

Much evidence supports a genetic basis for the predisposition to adverse normal tissue reactions after RT (McKay and Peters, 1997). Dysfunction of genes and their protein products involved in the sensing and response of cells to IR is therefore a potential

\footnotetext{
*Correspondence: Professor M McKay, Division of Radiation Oncology, Peter MacCallum Cancer Institute, Locked Bag I, A'Beckett Street, Melbourne, Victoria 8006, Australia

E-mail: m.mckay@pmci.unimelb.edu.au

Revised 7 January 2003; accepted 3 February 2003
}

mechanism of adverse normal tissue reactions to RT. Various approaches might be considered in attempts to unravel the molecular basis of clinical radiosensitivity. These include screening candidate radiosensitivity genes for mutations (Leong et al, 2000; Severin et al, 2001), adopting functional genomics approaches (e.g. using DNA microarrays) or, as adopted here, screening for abnormalities in key candidate proteins.

DNA double-strand breaks (dsbs) are the most lethal form of cellular DNA damage, and are major IR-induced DNA lesions (Jeggo, 1998a). Therefore, genes involved in processing this type of DNA lesion are excellent candidates for involvement in radiation hypersensitivity, and could account for all or a proportion of clinical RT hypersensitivity. In mammalian cells, the primary mechanism for repairing dsbs is nonhomologous end-joining (NHEJ) (Bryans et al, 1999). Genetic experiments indicate that the $\mathrm{Ku}$ heterodimer (Ku70 and Ku80), XRCC4 (X-ray repair cross complementing Chinese hamster ovary cell line) and DNA ligase $\overline{\mathrm{IV}}$ are required for efficient NHEJ in all eukaryotic species examined so far (Jeggo, 1998a). Mutation of any one of these four factors in both the budding yeast Saccharomyces cerevisiae (Herrmann et al, 1998; Wilson et al, 1997) and in mammalian cells (Frank et al, 1998; Gao et al, 1998a; Grawunder et al, 1998) yield very similar phenotypes, the features of which include defective DNA dsb repair and marked sensitivity to IR. In mammalian cells, NHEJ also requires the catalytic subunit of DNA-dependent protein kinase (DNA-PK $\mathrm{CS}_{\text {S }}$ (Jeggo, 1998a). However, an orthologue for this factor has not been found in the fully sequenced genome of $S$. cerevisiae. Even in species with a DNA-PK $\mathrm{CS}_{\mathrm{C}}$ orthologue, mutation sometimes results in a less severe phenotype than is observed for the other three components of the NHEJ pathway (Gao et al, 1998b; Taccioli et al, 1998). 
Given the radiation-sensitive phenotype displayed by mutants defective in components of the NHEJ pathway, in multiple eukaryotic species, we reasoned that these proteins were good candidates for screening for abnormalities in radiation-sensitive cancer patients. An abnormality in either the abundance of protein production or its molecular mass may be because of mutations in the corresponding gene, which could then be sequenced to identify the corresponding nucleotide sequence variant. We carried out and report here the results of Western blot analysis testing for abnormalities of DNA ligase IV, XRCC4, Ku70 and Ku80 in a cohort of severely radiosensitive cancer patients.

\section{MATERIALS AND METHODS}

\section{Patients (cases and controls)}

The patient cohort for this study comprised 36 radiation-sensitive individuals referred by radiation oncologists at Peter MacCallum Cancer Institute and several other centres within Australia. A highly radiosensitive response was defined as a clinically overt and unexpectedly severe radiation reaction (RTOG grades 3 and 4) which occurred either acutely (during or within weeks of completion of RT) or as a late adverse reaction (months to years after completion of the RT course) (Figure 1). A number of cases had controls (nonradiosensitive cancer patients) which were matched for the following factors: sex, age, tumour type, stage and grade and medications. The study was approved by the Peter MacCallum Cancer Institute Ethics Committee and all patients gave informed consent.

\section{Lymphoblastoid cell lines}

Blood was collected from each patient, from which lymphocytes were isolated by Ficoll gradient centrifugation and then transfected with Epstein-Barr virus to produce B-lymphoblastoid cell lines (LCLs) (Neitzel, 1986). These transformed lymphocytes were propagated as described (Leong et al, 2000) to provide an accessible source of protein extracts.

\section{SDS - polyacrylamide gel electrophoresis and Western blotting analysis}

Protein extracts were prepared from whole patient LCLs by sonication in SDS sample buffer. Equal amounts of protein from

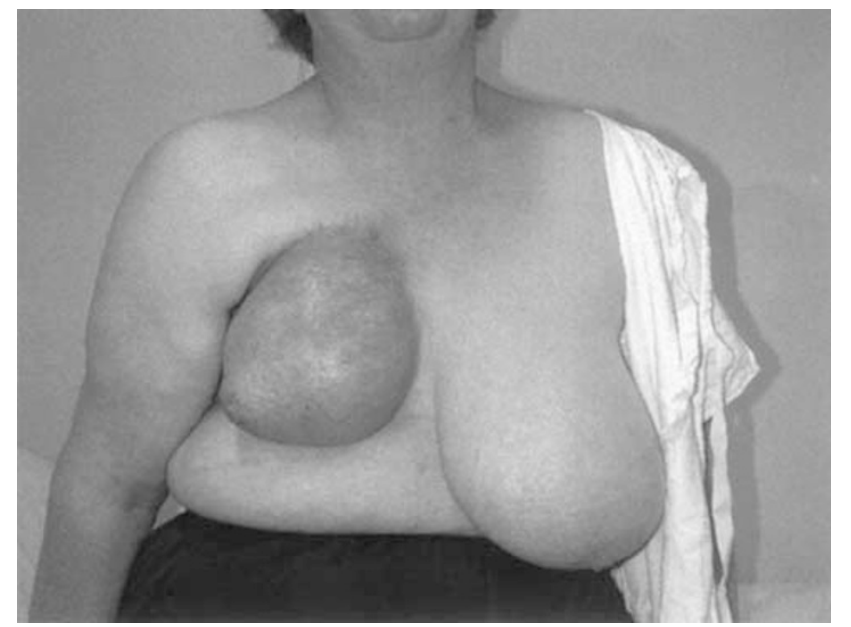

Figure I Photograph showing an example of a severe late radiation reaction. This patient (patient 8 in Table I) developed severe fibrosis, retraction and telangiectasia of the breast following routine postoperative RT for breast cancer. cases and controls (50 $\mu \mathrm{glane}^{-1}$ for ligase IV and XRCC4 gels; $15 \mu \mathrm{g} \mathrm{lane}^{-1}$ for Ku70 gels; $5 \mu \mathrm{g}$ lane $\mathrm{e}^{-1}$ for Ku80 gels) were loaded onto a $10 \%$ SDS - PAGE gel and subjected to electrophoresis. For Western blot analysis, separated proteins were transblotted onto PVDF membrane (PolyScreen PVDF Transfer Membrane, NEN Life Science Products, Boston, MA, USA) at a constant voltage of $100 \mathrm{~V}$ for $2 \mathrm{~h}$ in transfer buffer (25 mM Tris, $190 \mathrm{~mm}$ glycine, $20 \%$ $\mathrm{vv}^{-1}$ methanol), and the membrane blocked overnight in $10 \%$ skim milk. The membrane was probed with anti-DNA ligase IV (at 1000 -fold dilution), anti-XRCC4 (at 2500-fold dilution), anti-Ku70 (at 15000-fold dilution) or anti-Ku80 (at 15000-fold dilution) antibodies as the primary antibody and horseradish peroxidase conjugated goat anti-rabbit IgG as the secondary antibody (BIO$\mathrm{RAD}, \mathrm{CA}, \mathrm{USA})$. Protein products were then visualised by chemiluminescence (NEN Life Science Products, Boston, MA, USA) and autoradiography. We used gamma tubulin antibody (Wise et al, 2000) as an internal control to adjust for differences in the amount of protein loaded in each lane. The anti-DNA ligase IV antibody was raised against the C-terminal portion of the protein, while antibodies to XRCC4, Ku70 and Ku80 were raised against the full length of the protein. All primary antibodies were kindly provided by Drs Susan Critchlow and Stephen Jackson (Wellcome/ CRC Institute, Cambridge, UK).

\section{RESULTS}

A total of 36 patients were examined for evidence of defects in DNA ligase IV, XRCC4, Ku70 and Ku80 proteins using Western blotting (Table 1). Bands of reported and appropriate size were observed in all cases. Apparent molecular masses for DNA ligase IV, XRCC4, Ku70 and Ku80 proteins were 96, 55, 70 and $80 \mathrm{kDa}$, respectively. The screening analysis revealed no evidence of differences in expression level or of abnormal protein forms for any of the four proteins in the 36 radiosensitive patients tested, as compared to control patients (Figure 2). We would not expect any variation in protein levels for these NHEJ proteins in control patients.

\section{DISCUSSION}

In this study, we adopted a candidate protein approach to ascertain whether abnormalities in proteins which collaborate in the major dsb repair pathway, NHEJ, could be detected in cancer patients who had suffered severe RT side effects in their normal tissues. We therefore set out to determine whether defects in DNA ligase IV, XRCC4, Ku70 or Ku80 could account at least for some cases of radiation hypersensitivity. The screening analysis was performed using Western blotting. This method should detect any obvious differences in protein expression between radiosensitive and control patients which may have resulted from mutations in the corresponding genes. Despite an extensive analysis, we did not detect any differences in expression in the cohort of patients tested. We had also attempted to examine DNA-PK $\mathrm{CS}_{\mathrm{C}}$ using Western blotting. However, because of the large molecular mass of

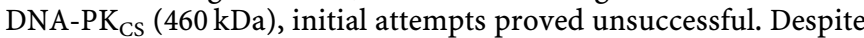
efforts to optimize the procedure by varying the parameters for electrophoresis and transblotting, we were unable to successfully perform the Western analysis for DNA-PK $\mathrm{CS}_{\mathrm{C}}$.

Although we failed to identify any NHEJ protein defects, this research is important for a number of reasons. First, studies such as this have the potential to contribute to the understanding of the mechanistic basis for clinical radiation hypersensitivity, which is currently largely unknown. Second, numerous mammalian cell lines and animals with naturally occurring or genetically engineered mutations in NHEJ components manifest radiosensitivity, including in the heterozygous state (see Introduction). The latter might be expected to be most likely to be revealed in 
Table I Patient characteristics

\begin{tabular}{|c|c|c|c|}
\hline Patient & Tumour & Radiotherapy schedule & Adverse reaction \\
\hline 1 & Carcinoma of breast & $46 \mathrm{~Gy}$ in $23 \mathrm{~F}$ plus boost $15 \mathrm{~Gy}$ in $5 \mathrm{~F}$ to breast & Severe fibrosis, retraction and telangiectasia. Rib fracture \\
\hline 2 & Carcinoma of breast & $46 \mathrm{~Gy}$ in $23 \mathrm{~F}$ plus boost $15 \mathrm{~Gy}$ in $5 \mathrm{~F}$ to breast & Severe fibrosis and retraction \\
\hline 3 & Carcinoma of breast & $50 \mathrm{~Gy}$ in $25 \mathrm{~F}$ to breast & Severe fibrosis and telangiectasia \\
\hline 4 & Carcinoma of breast & $46 \mathrm{~Gy}$ in $20 \mathrm{~F}$ to chest wall & Severe fibrosis and telangiectasia \\
\hline 5 & Carcinoma of breast & $46 \mathrm{~Gy}$ in $20 \mathrm{~F}$ to chest wall & Severe fibrosis and rib fractures \\
\hline 6 & Carcinoma of breast & $46 \mathrm{~Gy}$ in $20 \mathrm{~F}$ to chest wall & Soft tissue necrosis \\
\hline 7 & Carcinoma of breast & $50 \mathrm{~Gy}$ in $25 \mathrm{~F}$ to breast & $\begin{array}{l}\text { Severe acute moist desquamation. Severe fibrosis and } \\
\text { telangiectasia }\end{array}$ \\
\hline 8 & Carcinoma of breast & $50 \mathrm{~Gy}$ in $25 \mathrm{~F}$ plus boost $10 \mathrm{~Gy}$ in $5 \mathrm{~F}$ to breast & Severe fibrosis, retraction and telangiectasia \\
\hline 9 & Carcinoma of breast & $\begin{array}{l}18 \mathrm{~Gy} \text { in } 9 \mathrm{~F} \text { to breast (treatment terminated } \\
\text { prematurely) }\end{array}$ & $\begin{array}{l}\text { Severe acute reaction with moist desquamation, erythema } \\
\text { and oedema }\end{array}$ \\
\hline 10 & Carcinoma of breast & $50 \mathrm{~Gy}$ in $25 \mathrm{~F}$ plus boost $10 \mathrm{~Gy}$ in $5 \mathrm{~F}$ to breast & Severe fibrosis and telangiectasia \\
\hline 11 & Carcinoma of breast & $\begin{array}{l}45 \mathrm{~Gy} \text { in } 25 \mathrm{~F} \text { plus boost } 20 \mathrm{~Gy} \text { in } 10 \mathrm{~F} \text { to breast. } \\
48 \mathrm{~Gy} \text { in } 24 \mathrm{~F} \text { to supraclavicular fossa and axilla }\end{array}$ & $\begin{array}{l}\text { Severe fibrosis affecting breast, supraclavicular fossa and } \\
\text { axilla, causing excessive lymphoedema }\end{array}$ \\
\hline \multirow[t]{2}{*}{12} & Carcinoma of breast (bilateral) & $50 \mathrm{~Gy}$ in $25 \mathrm{~F}$ plus boost & $\begin{array}{l}\text { Severe acute reaction with moist desquamation, erythema } \\
\text { and oedema }\end{array}$ \\
\hline & & $10 \mathrm{~Gy}$ in $5 \mathrm{~F}$ to chest wall & \\
\hline 13 & Carcinoma of breast & $50 \mathrm{~Gy}$ in $25 \mathrm{~F}$ plus boost $10 \mathrm{~Gy}$ in $5 \mathrm{~F}$ to breast & $\begin{array}{l}\text { Severe acute reaction with erythema and oedema after } \\
\text { I0 Gy }\end{array}$ \\
\hline 14 & Carcinoma of breast & $46 \mathrm{~Gy}$ in $23 \mathrm{~F}$ plus boost $15 \mathrm{~Gy}$ in $5 \mathrm{~F}$ to breast & Severe fibrosis, retraction and telangiectasia \\
\hline 15 & Carcinoma of breast & $46 \mathrm{~Gy}$ in $23 \mathrm{~F}$ plus boost $15 \mathrm{~Gy}$ in $5 \mathrm{~F}$ to breast & Severe fibrosis and retraction \\
\hline 16 & Carcinoma of breast & $45 \mathrm{~Gy}$ in $25 \mathrm{~F}$ plus boost $15 \mathrm{~Gy}$ in $5 \mathrm{~F}$ to breast & $\begin{array}{l}\text { Severe acute reaction with moist desquamation and } \\
\text { oedema. Severe fibrosis, retraction and telangiectasia }\end{array}$ \\
\hline 17 & Carcinoma of breast & $\begin{array}{l}28 \mathrm{~Gy} \text { in } 14 \mathrm{~F} \text { to breast (treatment terminated } \\
\text { prematurely) }\end{array}$ & $\begin{array}{l}\text { Severe acute reaction with moist desquamation, erythema } \\
\text { and oedema }\end{array}$ \\
\hline 18 & Carcinoma of tonsillar fossa & $44 \mathrm{~Gy}$ in $22 \mathrm{~F}$ plus boost $16 \mathrm{~Gy}$ in $10 \mathrm{~F}$ & $\begin{array}{l}\text { Severe acute moist desquamation and mucositis requiring } \\
\text { nasogastric tube feeding for over I month }\end{array}$ \\
\hline 19 & Carcinoma of cervix & $\begin{array}{l}45 \mathrm{~Gy} \text { in } 25 \mathrm{~F} \text { plus } 30 \mathrm{~Gy} \text { to point } \mathrm{A} \text { in a single } \\
\text { insertion }\end{array}$ & $\begin{array}{l}\text { Small bowel damage requiring resection. Haemorrhagic } \\
\text { cystitis }\end{array}$ \\
\hline \multirow[t]{2}{*}{20} & Carcinoma of cervix & $\begin{array}{l}45 \mathrm{~Gy} \text { in } 25 \mathrm{~F} \text { plus } 30 \mathrm{~Gy} \text { to point } \mathrm{A} \text { in a single } \\
\text { insertion }\end{array}$ & Strictures of sigmoid colon and ureter requiring surgery \\
\hline & & & Peripheral neuropathy \\
\hline 21 & Carcinoma of cervix & $\begin{array}{l}54 \mathrm{~Gy} \text { in } 30 \mathrm{~F} \text { plus } 25 \mathrm{~Gy} \text { to point } \mathrm{A} \text { in a single } \\
\text { insertion }\end{array}$ & $\begin{array}{l}\text { Acute diarrhoea and bowel obstruction requiring surgical } \\
\text { resection }\end{array}$ \\
\hline 22 & Carcinoma of cervix & $\begin{array}{l}50 \mathrm{~Gy} \text { in } 25 \mathrm{~F} \text { plus } 25 \mathrm{~Gy} \text { to point } \mathrm{A} \text { in a single } \\
\text { insertion }\end{array}$ & Severe small bowel damage \\
\hline 23 & Carcinoma of anus & $28 \mathrm{~Gy}$ in $14 \mathrm{~F}$ (treatment terminated prematurely) & Severe moist desquamation \\
\hline 24 & Malignant melanoma & $50 \mathrm{~Gy}$ in $25 \mathrm{~F}$ to supraclavicular fossa & Severe moist desquamation during 4th week of RT \\
\hline 25 & Carcinoma of floor of mouth & $58 \mathrm{~Gy}$ in $29 \mathrm{~F}$ (treatment terminated prematurely) & $\begin{array}{l}\text { Severe acute mucositis } \\
\text { Late radionecrosis of mandible requiring resection }\end{array}$ \\
\hline 26 & Malignant thymoma & $50 \mathrm{~Gy}$ in $25 \mathrm{~F}$ to chest & Severe and prolonged acute oesophagitis for 6 weeks \\
\hline 27 & Carcinoma of lung & $60 \mathrm{~Gy}$ in $30 \mathrm{~F}$ to chest & Subacute pneumonitis \\
\hline 28 & Carcinoma of lung & $36 \mathrm{~Gy}$ in $12 \mathrm{~F}$ & $\begin{array}{l}\text { Acute, marked confluent erythema of skin. Subacute } \\
\text { pneumonitis }\end{array}$ \\
\hline 29 & Transitional cell carcinoma of urethra & $50 \mathrm{~Gy}$ in $25 \mathrm{~F}$ to pelvis & Avascular necrosis of hip \\
\hline 30 & Carcinoma of prostate & $64 \mathrm{~Gy}$ in $32 \mathrm{~F}$ to pelvis & $\begin{array}{l}\text { Radiation proctitis with PR bleeding requiring laser } \\
\text { treatment }\end{array}$ \\
\hline 31 & Carcinoma of prostate & $60 \mathrm{~Gy}$ in $30 \mathrm{~F}$ to pelvis & Radiation proctitis with severe PR bleeding \\
\hline 32 & Carcinoma of prostate & $66 \mathrm{~Gy}$ in $33 \mathrm{~F}$ to pelvis & Radiation proctitis with severe PR bleeding \\
\hline 33 & Carcinoma of prostate & $64 \mathrm{~Gy}$ in $32 \mathrm{~F}$ to pelvis & Radiation proctitis with severe PR bleeding \\
\hline 34 & Carcinoma of prostate & $66 \mathrm{~Gy}$ in $33 \mathrm{~F}$ to pelvis & $\begin{array}{l}\text { Radiation proctitis with PR bleeding requiring laser } \\
\text { treatment }\end{array}$ \\
\hline 35 & Carcinoma of prostate & $64 \mathrm{~Gy}$ in $32 \mathrm{~F}$ to pelvis & $\begin{array}{l}\text { Radiation proctitis with PR bleeding requiring laser } \\
\text { treatment }\end{array}$ \\
\hline 36 & Carcinoma of prostate & $64 \mathrm{~Gy}$ in $32 \mathrm{~F}$ to pelvis & Radiation proctitis with severe PR bleeding \\
\hline
\end{tabular}

Gy=gray; F=fractions.

screening studies such as reported here. Third, there is a precedent for detection of abnormal ligase IV on Western analysis in a radiosensitive individual: a leukaemia patient with fatal radiosensitivity has been identified to carry a mutation in a NHEJ protein, with an abnormal pattern on Western analysis (Riballo et al, 1999). Although this patient appears to have suffered a more dramatic adverse radiation reaction compared to the patients in our cohort, it is difficult to make direct comparisons. There is currently no clear picture of the spectrum of severe adverse radiation reactions that are seen in the clinical setting. One factor determining the outcome of an adverse radiation reaction is the organ that has been irradiated. For example, the consequences of a severe reaction in skin (e.g. fibrosis) would be far less dramatic than that seen in the spinal cord (e.g. paraplegia). This patient with a mutation in ligase IV was a young child who had received radiation to a developing brain. There are no similar patients in our cohort who had received cranial irradiation for comparison. We aimed to further evaluate this reported experience to 
A

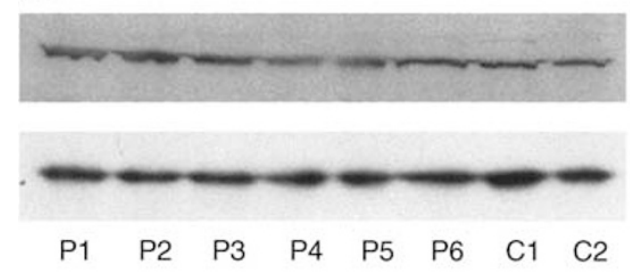

C
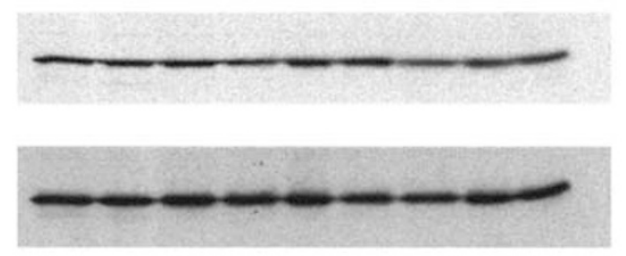

$\begin{array}{llllllllll}\text { C1 } & \text { P1 } & \text { P2 } & \text { P3 } & \text { P4 } & \text { P5 } & \text { P6 } & \text { P7 } & \text { C2 }\end{array}$
B

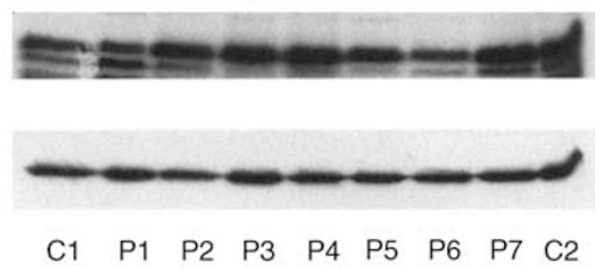

D

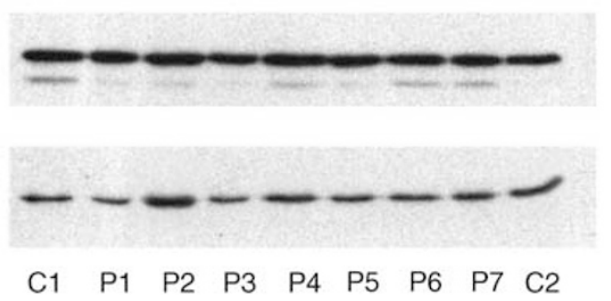

Figure 2 Typical Western blot analysis of protein extracts from radiosensitive patients using $(\mathbf{A})$ anti-DNA ligase IV, (B) anti-XRCC4, (C) anti-Ku70 and (D) anti-Ku80 antibodies. There were no differences in expression for any of the four proteins between radiosensitive and control patients. Gamma-tubulin was used as an internal control to adjust for differences in the amount of protein loaded in each lane (lower autoradiograph in each panel). $\mathrm{P}=$ radiosensitive patient, $\mathrm{C}=$ control patient.

determine its generalisability to other radiosensitive cancer patients. Collectively, these considerations formed a logical rationale for the present investigations.

Although a variety of factors could theoretically influence radiosensitivity, strong evidence implicates a genetic basis for the predisposition to adverse normal tissue RT reactions. In recent years, realisation of a probable genetic basis for radiosensitivity has led to searches for genetic aberrations that could be used as predictive assays. Screening for heterozygous mutations in the gene homozygously mutated in the cancer-prone, radiosensitivity disorder, ataxia-telangiectasia (ATM: AT mutated) in radiosensitive patients has been vigorously pursued during the past few years. However, data from several studies suggest that ATM gene defects are not a major cause of radiation hypersensitivity (Appleby et al, 1997; Clarke et al, 1998; Hall et al, 1998; Ramsay et al, 1998; Shayeghi et al, 1998; Oppitz et al, 1999). We have previously reported the results of mutation analysis of BRCA1 and BRCA2 cancer predisposition genes in a cohort of radiationhypersensitive cancer patients (Leong et al, 2000).

Of the many types of DNA damage that can occur, dsbs are a critical event leading to cell death if the break remains unrepaired or is repaired improperly. Studies with mammalian cells have suggested that the majority of dsbs are rejoined by NHEJ. Studies using IR-sensitive mutant rodent cells have identified five factors involved in this process; Ku70, Ku80, XRCC4, DNA ligase IV and

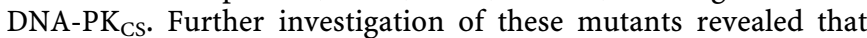
these proteins were also required for $\mathrm{V}(\mathrm{D}) \mathrm{J}$ recombination, the process in $\mathrm{B}$ and $\mathrm{T}$ cells which allows immunological diversity during antibody and $\mathrm{T}$-cell receptor production, indicating that these two fundamental DNA transactions share common components (Pergola et al, 1993).

Several murine and human models have highlighted the critical role that all these factors play in DNA dsb repair. Targeted disruption of the gene encoding DNA ligase IV leads to late embryonic lethality and impaired $\mathrm{V}(\mathrm{D}) \mathrm{J}$ recombination in mice (Barnes et al, 1998; Frank et al, 1998). Ligase IV-deficient embryonic fibroblasts also show marked sensitivity to IR (Frank et al, 1998). 180BR is a radiosensitive fibroblast cell line derived from a leukaemia patient who over-responded to RT and subsequently died of radiation morbidity. 180BR cells were shown to harbour a homozygous missense mutation in the ATP binding domain of human DNA ligase IV (Riballo et al, 1999). DNA ligase IV mutations have also been identified recently in several patients exhibiting developmental delay and immunodeficiency, and cell lines derived from these patients exhibit pronounced radiosensitivity (O'Driscoll et al, 2001). XRCC4 forms a tight complex with DNA ligase IV in mammalian cells. Recombinant XRCC4 protein stimulates DNA binding and the ligation activity of DNA ligase IV in vitro (Grawunder et al, 1997). Mice with targeted disruption of the gene encoding XRCC4 have growth defects, premature senescence, impaired $\mathrm{V}(\mathrm{D}) \mathrm{J}$ recombination and marked sensitivity to IR (Gao et al, 1998a). Ku has at least three separate functions in end-joining DNA dsb repair that have been identified in vitro. It generally facilitates end-joining by aligning DNA ends, and it specifically recruits both XRCC4-ligase IV and DNA-PK $\mathrm{CS}_{\mathrm{CS}}$ to DNA ends (Nick_McElhinny et al, 2000). Ku80-deficient ES cells and pre-B-cell lines are hypersensitive to IR (Nussenzweig et al, 1997) and consistent with the radiation-hypersensitive phenotype of the cell lines, Ku80 mutant mice also display extreme radiosensitivity (Nussenzweig et al, 1997). Mice lacking Ku70 are immunodeficient and growth retarded, and Ku70-deficient ES cells have increased radiosensitivity, defective DNA end binding activity and an inability to support V(D)J recombination (Gu et al, 1997a, b). In mammalian cells, NHEJ also typically requires DNA-PK $\mathrm{CS}_{\mathrm{CS}}$.

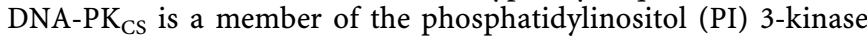
family that is activated upon binding to DNA ends. Cells derived from highly radiosensitive SCID mice have a DNA dsb repair deficiency caused by a mutation in the DNA-PK $\mathrm{CS}_{\mathrm{C}}$ gene. However, there are circumstances where mutation of DNA-PK ${ }_{\mathrm{CS}}$ still allows much greater levels of end-joining than are observed when $\mathrm{Ku}$, XRCC4 or ligase IV is mutated. For example, mice completely deficient in $\mathrm{DNA}-\mathrm{PK}_{\mathrm{CS}}$ can join signal end intermediates in $\mathrm{V}(\mathrm{D}) \mathrm{J}$ recombination, and ES cells from such mice possess a normal level of resistance to IR (Gao et al, 1998b; Taccioli et al, 1998). The function of DNA-PK $\mathrm{CS}_{\mathrm{CS}}$ in NEJ therefore may be more dispensable than that of Ku, XRCC4 or ligase IV, depending on the organism, cell type and molecular context of the ends to be joined (Nick_McElhinny et al, 2000).

In summary, the involvement of DNA ligase IV, XRCC4, Ku70 and $\mathrm{Ku} 80$ in dsb repair, and the radiosensitive phenotype 
displayed by mouse and human mutants in these NHEJ components, justified analysis of these proteins in our cohort of radiation-hypersensitive patients. We screened a highly selected group of cancer patients with severe adverse reactions to standard RT for defects in four of the five major NHEJ components using Western analysis: no defects were detected. These results suggest that mutations that affect protein expression of these factors do not account for most cases of clinical radiation hypersensitivity, and that screening for abnormalities of these factors using Western blotting might be unlikely to be useful for predicting clinical response to RT. However, we have not completely excluded that defects in the NHEJ pathway may contribute to clinical radio- sensitivity. It is possible that mutational changes that confer radiosensitivity but have no other easily detectable impact may be missense or subtle mutations that may not affect dramatically protein levels. Also, we have not excluded that defects in DNA$\mathrm{PK}_{\mathrm{CS}}$ might contribute to clinical radiosensitivity. Since mutations of DNA ligase IV account for some instances of radiation hypersensitivity, we are examining further radiosensitive individuals for abnormal DNA ligase IV protein expression. Ongoing candidate gene/protein analyses in radiosensitive cancer patients are expected to yield further examples of the range of molecular defects causing human radiosensitivity.

\section{REFERENCES}

Appleby JM, Barber JB, Levine E, Varley JM, Taylor AM, Stankovic T, Heighway J, Warren C, Scott D (1997) Absence of mutations in the ATM gene in breast cancer patients with severe responses to radiotherapy. $\mathrm{BrJ}$ Cancer 76: $1546-1549$

Barnes DE, Stamp G, Rosewell I, Denzel A, Lindahl T (1998) Targeted disruption of the gene encoding DNA ligase IV leads to lethality in embryonic mice. Curr Biol 8: 1395-1398

Bryans M, Valenzano MC, Stamato TD (1999) Absence of DNA ligase IV protein in XR-1 cells: evidence for stabilization by XRCC4. Mutat Res 433: $53-58$

Clarke RA, Goozee GR, Birrell G, Fang ZM, Hasnain H, Lavin M, Kearsley JH (1998) Absence of ATM truncations in patients with severe acute radiation reactions. Int J Radiat Oncol Biol Phys 41: 1021 - 1027

Frank KM, Sekiguchi JM, Seidl KJ, Swat W, Rathbun GA, Cheng HL, Davidson L, Kangaloo L, Alt FW (1998) Late embryonic lethality and impaired V(D)J recombination in mice lacking DNA ligase IV. Nature 396: $173-177$

Gao Y, Chaudhuri J, Zhu C, Davidson L, Weaver DT, Alt FW (1998b) A targeted DNA-PKcs-null mutation reveals DNA-PK-independent functions for $\mathrm{KU}$ in $\mathrm{V}(\mathrm{D}) \mathrm{J}$ recombination. Immunity 9: 367-376

Gao Y, Sun Y, Frank KM, Dikkes P, Fujiwara Y, Seidl KJ, Sekiguchi JM, Rathbun GA, Swat W, Wang J, Bronson RT, Malynn BA, Bryans M, Zhu C, Chaudhuri J, Davidson L, Ferrini R, Stamato T, Orkin SH, Greenberg ME, Alt FW (1998a) A critical role for DNA end-joining proteins in both lymphogenesis and neurogenesis. Cell 95: 891-902

Grawunder U, Wilm M, Wu X, Kulesza P, Wilson TE, Mann M, Lieber MR (1997) Activity of DNA ligase IV stimulated by complex formation with XRCC4 protein in mammalian cells. Nature 388: $492-495$

Grawunder U, Zimmer D, Fugmann S, Schwarz K, Lieber MR (1998) DNA ligase IV is essential for V(D)J recombination and DNA double-strand break repair in human precursor lymphocytes. Mol Cell 2: 477-484

Gu Y, Jin S, Gao Y, Weaver DT, Alt FW (1997a) Ku70-deficient embryonic stem cells have increased ionizing radiosensitivity, defective DNA endbinding activity, and inability to support V(D)J recombination. Proc Natl Acad Sci USA 94: 8076-8081

Gu Y, Seidl KJ, Rathbun GA, Zhu C, Manis JP, van_der_Stoep N, Davidson L, Cheng HL, Sekiguchi JM, Frank K, Stanhope_Baker P, Schlissel MS, Roth DB, Alt FW (1997b) Growth retardation and leaky SCID phenotype of Ku70-deficient mice. Immunity 7: 653-665

Hall EJ, Schiff PB, Hanks GE, Brenner DJ, Russo J, Chen J, Sawant SG, Pandita TK (1998) A preliminary report: frequency of A-T heterozygotes among prostate cancer patients with severe late responses to radiation therapy. Cancer J Sci Am 4: 385-389

Herrmann G, Lindahl T, Schar P (1998) Saccharomyces cerevisiae LIF1: a function involved in DNA double-strand break repair related to mammalian XRCC4. EMBO J 17: 4188-4198

Jeggo PA (1998a) Identification of genes involved in repair of DNA doublestrand breaks in mammalian cells. Radiat Res 150: $\mathrm{S} 80-\mathrm{S} 91$

Leong T, Whitty J, Keilar M, Mifsud S, Ramsay J, Birrell G, Venter D, Southey M, McKay M (2000) Mutation analysis of BRCA1 and BRCA2 cancer predisposition genes in radiation hypersensitive cancer patients. Int J Radiat Oncol Biol Phys 48: 959-965
McKay M, Peters L (1997) Genetic determinants of radiation response. Report on a symposium held at Peter MacCallum Cancer Institute, Melbourne, Australia, 8 August 1996. Int J Radiat Biol 71: 225-229

Neitzel H (1986) A routine method for the establishment of permanent growing lymphoblastoid cell lines. Hum Genet 73: 320-326

Nick_McElhinny SA, Snowden CM, McCarville J, Ramsden DA (2000) $\mathrm{Ku}$ recruits the XRCC4-ligase IV complex to DNA ends. Mol Cell Biol 20: $2996-3003$

Norman A, Kagan AR, Chan SL (1988) The importance of genetics for the optimization of radiation therapy. A hypothesis. Am J Clin Oncol 11: $84-88$

Nussenzweig A, Sokol K, Burgman P, Li L, Li GC (1997) Hypersensitivity of Ku80-deficient cell lines and mice to DNA damage: the effects of ionizing radiation on growth, survival, and development. Proc Natl Acad Sci USA 94: $13588-13593$

O'Driscoll M, Cerosaletti KM, Girard PM, Dai Y, Stumm M, Kysela B, Hirsch B, Gennery A, Palmer SE, Seidel J, Gatti RA, Varon R, Oettinger MA, Neitzel H, Jeggo PA, Concannon P (2001) DNA ligase IV mutations identified in patients exhibiting developmental delay and immunodeficiency. Mol Cell 8: 1175-1185

Oppitz U, Bernthaler U, Schindler D, Sobeck A, Hoehn H, Platzer M, Rosenthal A, Flentje M (1999) Sequence analysis of the ATM gene in 20 patients with RTOG grade 3 or 4 acute and/or late tissue radiation side effects. Int J Radiat Oncol Biol Phys 44: 981 - 988

Pergola F, Zdzienicka MZ, Lieber MR (1993) V(D)J recombination in mammalian cell mutants defective in DNA double-strand break repair. Mol Cell Biol 13: 3464-3471

Ramsay J, Birrell G, Lavin M (1998) Testing for mutations of the ataxia telangiectasia gene in radiosensitive breast cancer patients. Radiother Oncol 47: $125-128$

Riballo E, Critchlow SE, Teo SH, Doherty AJ, Priestley A, Broughton B, Kysela B, Beamish H, Plowman N, Arlett CF, Lehmann AR, Jackson SP, Jeggo PA (1999) Identification of a defect in DNA ligase IV in a radiosensitive leukaemia patient. Curr Biol 9: 699-702

Severin DM, Leong T, Cassidy B, Elsaleh H, Peters L, Venter D, Southey M, McKay M (2001) Novel DNA sequence variants in the hHR21 DNA repair gene in radiosensitive cancer patients. Int J Radiat Oncol Biol Phys 50: $1323-1331$

Shayeghi M, Seal S, Regan J, Collins N, Barfoot R, Rahman N, Ashton A, Moohan M, Wooster R, Owen R, Bliss JM, Stratton MR, Yarnold J (1998) Heterozygosity for mutations in the ataxia telangiectasia gene is not a major cause of radiotherapy complications in breast cancer patients. $\mathrm{Br} \mathrm{J}$ Cancer 78: $922-927$

Taccioli GE, Amatucci AG, Beamish HJ, Gell D, Xiang XH, Torres_Arzayus MI, Priestley A, Jackson SP, Marshak_Rothstein A, Jeggo PA, Herrera VL (1998) Targeted disruption of the catalytic subunit of the DNA-PK gene in mice confers severe combined immunodeficiency and radiosensitivity. Immunity 9: 355-366

Wilson TE, Grawunder U, Lieber MR (1997) Yeast DNA ligase IV mediates non-homologous DNA end joining. Nature 388: 495-498

Wise DO, Krahe R, Oakley BR (2000) The gamma-tubulin gene family in humans. Genomics 67: 164-170 